\title{
Autosomal recessive severe congenital neutropenia due to CXCR2 deficiency
}

INSERM

\section{Source}

INSERM. (1999). Orphanet: an online rare disease and orphan drug data base. Autosomal recessive severe congenital neutropenia due to CXCR2 deficiency. ORPHA:420699

Autosomal recessive severe congenital neutropenia due to CXCR2 deficiency is a rare, genetic, primary immunodeficiency disorder characterized by recurrent bacterial infections (including septic thrombophlebitis and subacute bacterial endocarditis) and neutropenia without lymphopenia or warts, resulting from recessively inherited mutations in $\mathrm{CXCR} 2<\mathrm{i} />$. 